\title{
EDITORIAL
}

\section{THE IMPORTANCE OF SELF- ARCHIVING IN LIGHT OF THE NEW FUNDING PARADIGM}

\author{
João de Deus Barreto*, Katia Nunes Sá** \\ * Scientific Communications Analyst (Scientific Communications Unit - Bahiana School of Medicine and Public Health) nucc- \\ joaosegundo@bahiana.edu.br \\ ** Full professor and Scientific Communications Unit Coordinator at Bahiana School of Medicine and Public Health katia. \\ sa@bahiana.edu.br
}

The world is changing ever faster in every field, specially in scientific research and reporting. Twenty six years ago, Cold Ward lead to massive governmental funding in research. From 1945 to 1989, every effort was made by both Eastern and Western political powerhouses to ensure that blue sky - research without clear applications - and applied research would result in political capital gains to feed the public international clash of ideologies. In spite of the fruitless political supremacy claims, the war effort left humanity legacies such as space travel and atom fissuring, not to mention everyday comforts such as Teflon. Yet, the investment paradigm has now shifted again and is oriented towards applicability. ${ }^{(1)}$ By the end of the War, research was left at the hands of government funded think tanks, private sector transnational companies, and public and private higher education institutions which are now required by the society to return the public investments in the form of life quality improvements and shared open access knowledge such as institutional repositories. Hence, new forms of research impact assessment are emerging and being put to test. ${ }^{(1,2)}$

As funding becomes scarce and strategic oriented, data, thanks to technological advancements, is more available to everyone around the globe through the internet in repositories, a phenomenon that is part of the new economy of scope paradigm and presents an opportunity to scientists dealing with funding contingency. ${ }^{(1,3)} \mathrm{A}$ researcher is nowadays promptly required to answer questions such as if their research could improve life quality or how many jobs it is going to create. (4) Being so, institutional repositories offer the scientists the possibility to gather data and literature and carefully plan their research effort beforehand and even save costs in buying literature from copyrighted journals. (3) This way, it can be fathomed what could be achieved and they can justify the funding agencies investment.

When it comes to physiotherapy, even in spite of the Brazilian government effort, high quality scientific research reports are still hard to come by ${ }^{(5)}$ and that is why self archiving in institutional repositories can be so important to this particular field of science. The more scientists self archive their production in high quality higher education institution's repositories, the more high quality knowledge will be available to all, strengthening the field as a whole in Brazil and worldwide.

There are over 24 thousand scientific journals being published worldwide with around 2,5 million manuscripts a year. Around $15 \%$ of that is being currently archived in repositories. ${ }^{(3)}$ Now, that is a 
very expressive amount of open access worldwide accessible knowledge to the advancement of science and society as a whole.

You can access Bahiana School of Medicine and Human Health's repository at the following URL: www.repositorio.bahiana.edu.br.

\section{REFERENCES}

1. Roosendaal HE, Geurts PAThM. Forces and functions in scientific communication: an analysis of their interplay. In: Conference on Co-operative Research in Information Systems in Physics, 1997, September 1-3, University of Oldenburg, Germany. P. 1-32
2. Samuel GN, Derrick, GE. Societal impact evaluation: Exploring evaluator perceptions of the characterization of impact under the REF2O14. Research Evaluation 2015 Apr;24(16):229-241. doi:10.1093/reseval/rvvOO7

3. Leite FCL. Como gerenciar e ampliar a visibilidade da informação científica brasileira: repositórios institucionais de acesso aberto. Brasília: IBICT; 2009.

4. Andrade JB, Cadore S, Vieira PC, Zucco C, Pinto AC. Eixos Mobilizadores em Química. Quim. Nova 2003;26(3):445-451.

5. Sá KN, Garboggini, PVSL. O Acesso Livre à Informação e a Ciência em Fisioterapia. Revista Pesquisa em Fisioterapia 2014 Dez;4(3):171-172. 